\title{
Hydrogen photoproduction by algae and higher plants: Optimal conditions for polarographic determination
}

\author{
G KULANDAIVELU, V RAVI and A THANGARAJ \\ School of Biological Sciences. Madurai Kamaraj University, Madurai 625 021, India
}

\begin{abstract}
Photosynthetic $\mathrm{H}_{2}$ production capacity has been studied using a $\mathrm{H}_{2}$ sensitive electrode in green and blue-green algae. higher plant cells and chloroplasts and photosynthetic bacteria. Among the cell types tried, Anacistis showed the maximum rate of $\mathbf{H}_{2}$ production. All the cell types require either an electron acceptor or a reductant fsodium dithionitel for $\mathrm{H}_{2}$ production. In the presence of an electron acceptor or reductant $\mathbf{H}_{2}$ production was observed even in unadapted cells. Cultures of Anacystis grown for a maximum period of 70 days showed a high rate of $\mathrm{H}_{2}$ production up to 40 days. The light saturation curves and $\mathrm{pH}$ optima for $\mathrm{H}_{2}$ production were similar to that of $\mathrm{O}_{2}$ evolution in the cell types studied.
\end{abstract}

Keywords. Hydrogen production; algae; mesophyll cells; polarography; optimal conditions.

\section{Introduction}

During the past few years, research on alternate energy sources has been gaining serious attention. Biological conversion of solar energy to $\mathrm{H}_{2}$ is one such emerging field of interest. All 'biological' energy conversion systems depend on the process of photosynthesis. The enormous potential of biological $\mathrm{H}_{2}$ producing system has been well documented in several reviews (Calvin 1976; Hall 1978; Mitsui 1979).

Intact cells of the heterocystous, filamentous cyanobacteria have been reported to evolve $\mathrm{O}_{2}$ and nitrogenase-mediated $\mathrm{H}_{2}$ under continuous illumination. In eukaryotic green algae, $\mathrm{H}_{2}$ production via hydrogenase has been suggested to occur either by photosystem II (PS II) or photosystem I (PS I) and these organisms have also been the subject of a great deal of research tuwards solar energy conversion. Over the past two decades many workers have demonstrated that photosynthetic electron flow of isolated higher plant chloroplasts could be coupled to hydrogenase to allow $\mathrm{H}_{2}$ production. However, there is no experimental evidence to suggest the existence of hydrogenase in higher plants.

In this paper, we present our results in establishing ideal measuring conditions for high rate of $\mathrm{H}_{2}$ production in a variety of algae, bacteria and higher plant species. For most of the experiments, polarographic method was used for its simplicity and also for its capacity to detect the immediate release of $\mathrm{H}_{2}$ by the photosynthetic organisms.

\section{Materials and methods}

\subsection{Algal and bacterial cultures}

The eucaryotic, unicellular green alga Scenedesmus obliquus D3 strain was grown photoautotrophically in culture tubes using the medium devised by Bishop and Senger (1971). The green alga Chlorella protothecoides was grown photoautotrophi- 
cally in Sorokin and Krauss (1958) liquid culture medium. Aeration was given throughout the culture period of the cells and care was taken in every step to avoid bacterial and fungal contamination.

The unicellular blue green alga Anacystis nidulans (IU 625), the filamentous heterocystous blue green algae, Anabaena and Nostoc corneum were grown in modified Allen's (1968) medium.

The unicellular photosynthetic bacterium Rhodopseudomonas palustris (DSM No. 123) and Rhodopseudomonas capsulata (DSM No. 1710) were grown photoautotrophically in the medium devised by Bose (1963).

\subsection{Plant materials}

Seedlings of Pisum sativum, Dolichos lab lab and Ipomoea were grown under field condition in botanic garden.

\subsection{Isolation of chloroplasts and mesophyll cells}

Type C broken chloroplasts were isolated from Pisum leaves as described by Takaoki et al (1974). Mesophyll cells from fresh fully expanded leaves of Dolichos and I pomoea were isolated according to the method of Gnanam and Kulandaivelu (1969).

\subsection{Measurements}

Photosynthetic $\mathrm{O}_{2}$ exchange reaction was monitored using a Clark type $\mathrm{O}_{2}$ electrode. For $\mathrm{H}_{2}$ measurements, the same kind of electrode polarized at $+0.8 \mathrm{~V}$ as suggested by Wang et al (1971) was used. The reaction was carried out in a $3 \mathrm{ml}$ water jacketed glass vessel at $25^{\circ} \mathrm{C}$. Saturating white light was provided by a slide projector. Irradiation was measured using a Li-Cor Ll-188B quantum/radiometer. Total chlorophyll was determined by the method of Arnon (1949). The bacteriochlorophyll content was estimated using the $\mathrm{mM}$ extinction coefficient of $75 \mathrm{~cm}^{-1}$ (Clayton 1963). Packed cell volume (PCV) was determined according to Senger (1970) using hematocrit tubes.

\section{Results and discussion}

In an attempt to optimise the measurement conditions for $\mathrm{H}_{2}$ evolution in a variety of organisms we have selected unicellular and filamentous cyanobacteria, green algae and isolated mesophyll cells and chloroplasts from a few higher plant species. Typical kinetics of $\mathrm{H}_{2}$ evolution in Anacystis are shown in figure 1 . The cells require addition of either an electron acceptor (BQ) or a reductant (dithionite) for $\mathrm{H}_{2}$ evolution. In the absence of any of these compounds, no $\mathrm{H}_{2}$ evolution could be detected. This reaction is coupled to photosynthesis as addition of either $B Q$ or dithionite alone in the reaction mixture yielded no $\mathrm{H}_{2}$ evolution. The kinetics of $\mathrm{H}_{2}$ evolution observed in these organisms resemble those reported for Scenedesmus (Senger and Bishop 1979), Anacystis (Peschek 1979a, b) and Anabaena (Houchins and Burris 1981a, b). 


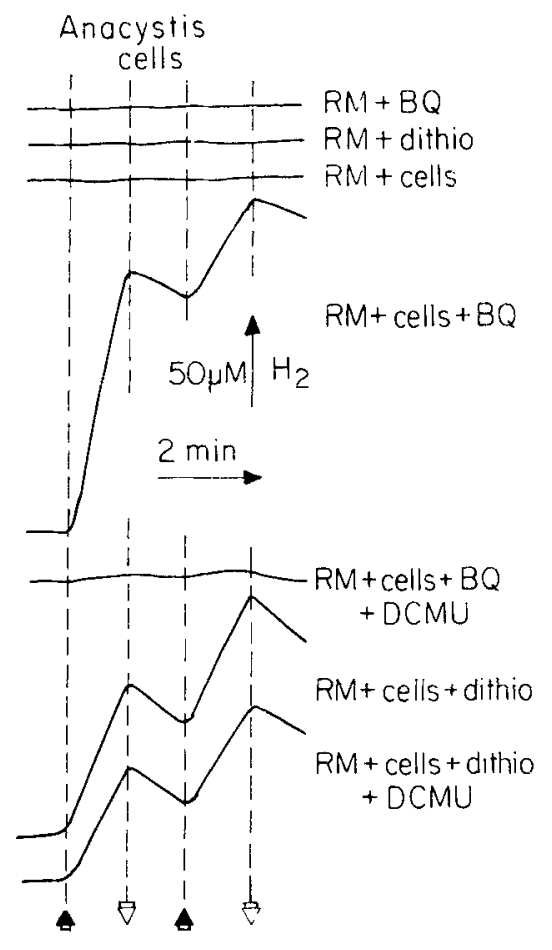

Figure 1. Original polarographic tracings of $\mathrm{H}_{2}$ evolution in Anarystis cells. Open and closed arrows indicate light on and off respectively.

Comparative rates of $\mathrm{H}_{2}$ evolution mediated by $\mathrm{BQ}$ and dithionite and photosynthetic $\mathrm{O}_{2}$ evolution in a variety of organisms are presented in table 1 . Among the organisms tried, the cyanobacteria showed higher rate of $\mathrm{H}_{2}$ evolution than photosynthetic bacteria, green algae and isolated mesophyll cells of higher plants. The green algae and mesophyll cells showed approximately equal rate of $\mathrm{H}_{2}$ evolution while Anucystis among cyanobacteria showed the highest rate of $\mathrm{H}_{2}$ evolution in the presence of either $\mathrm{BQ}$ or dithionite. In all the oxygenic photosynthetic systems, the BQ-mediated $\mathrm{H}_{2}$ evolution exceeded $50 \%$ of the rate of $\mathrm{O}_{2}$ evolution.

\section{1 $\mathrm{H}_{2}$ evolution in ageing algal and bacterial cultures}

As the culture ages, the nutrients in the medium get depleted, the average intensity of light within the culture decreases, the average spectral distribution of light within the culture changes : $\mathrm{a}$ the metabolic rate of cells also changes from day to day. Hence the influence of culture age on the rate of $\mathrm{H}_{2}$ evolution was followed in the selected cell types.

Changes in the rate of $\mathrm{H}_{2}$ evolution and uptake as a function of culture age in Anacystis are shown in figure 2 . In this culture the log phase lasts for almost 25 days and the stationary phase up to 40 days. The culture starts decaying after 40 days. The maximum rate of $\mathrm{BQ}$ mediated $\mathrm{H}_{2}$ and $\mathrm{O}_{2}$ evolution was observed in the log and early stationary phase (5-30 days). Contrary to the changes observed in BQ 
Table 1. Rates of $\mathrm{H}_{2}$ and $\mathrm{O}_{2}$ evolution in different cell systems. For details on measurement conditions see materials and method.

\begin{tabular}{|c|c|c|c|}
\hline \multirow[b]{2}{*}{ Cells } & \multicolumn{2}{|c|}{$\mathrm{H}_{2} \mu$ mol.mg. $\mathrm{Chl}^{-1} \mathrm{~h}^{-1}$} & \multirow[b]{2}{*}{$\begin{array}{c}\mathrm{O}_{2} \mu \mathrm{mol} . \mathrm{mg} . \\
\mathrm{Chl}^{-1} \mathrm{~h}^{-1}\end{array}$} \\
\hline & $\mathbf{B Q}$ & $\begin{array}{c}\text { + Dithionite } \\
\text { DCMU }(10 \mu \mathrm{M})\end{array}$ & \\
\hline $\begin{array}{l}\text { Rhodopseudomonas } \\
\text { capsulata }\end{array}$ & 87.8 & $52 \cdot 1$ & 0 \\
\hline $\begin{array}{l}\text { Rhodopseudomonas } \\
\text { palustris }\end{array}$ & $96 \cdot 3$ & $47 \cdot 4$ & 0 \\
\hline Anacystis nidulans & $178 \cdot 2$ & $79 \cdot 3$ & $247 \cdot 7$ \\
\hline Anabaena sp. & $162 \cdot 0$ & $68 \cdot 7$ & $223 \cdot 0$ \\
\hline Calothrix sp. & $98 \cdot 4$ & $53 \cdot 0$ & 196.0 \\
\hline Nostoc corneum & $146 \cdot 4$ & $44 \cdot 6$ & 2660 \\
\hline Oscillatoria sp. & $157 \cdot 7$ & $43 \cdot 1$ & $245 \cdot 0$ \\
\hline Tolypothrix sp. & $129 \cdot 0$ & $56 \cdot 2$ & $237 \cdot 0$ \\
\hline Chlorella protothecoides & $103 \cdot 6$ & $53 \cdot 4$ & $258 \cdot 5$ \\
\hline Scenedesmus obliquus & $112 \cdot 6$ & $42 \cdot 1$ & $256 \cdot 3$ \\
\hline Arachis hypogea & $105 \cdot 0$ & $59 \cdot 2$ & $237 \cdot 6$ \\
\hline Dolichos lab lab & $108 \cdot 2$ & $71 \cdot 3$ & $247 \cdot 7$ \\
\hline Erythrina indica & $101 \cdot 9$ & $56 \cdot 9$ & $228 \cdot 8$ \\
\hline Ipomoea pentaphylla & $94 \cdot 1$ & $67 \cdot 3$ & $231 \cdot 4$ \\
\hline Musa paradisiaca & $96 \cdot 2$ & $61 \cdot 8$ & $203 \cdot 5$ \\
\hline Thunbergia grandiflora & $102 \cdot 9$ & $41 \cdot 5$ & $226 \cdot 8$ \\
\hline
\end{tabular}

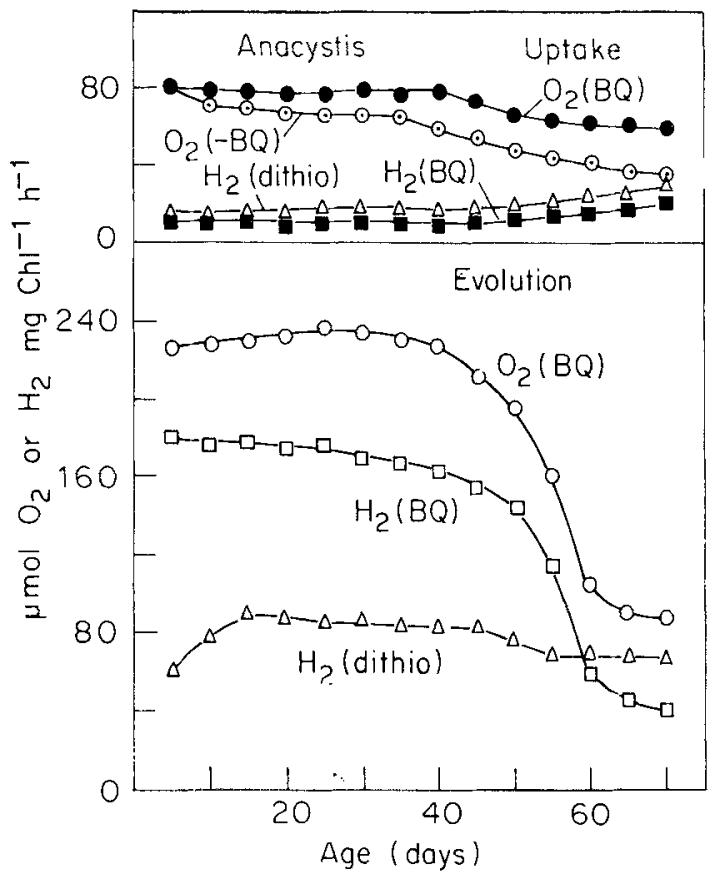

Figure 2. Changes in the rate of $\mathrm{H}_{2}$ and $\mathrm{O}_{2}$ evolution (open symbols) and uptake (closed and partially closed symbols) as a function of age in autotrophically grown cultures of Anacystis. 
mediated reaction, dithionite-mediated rates remained highly stable even in the decay phase of the culture. This could be due to the fact that the dithionite mediated reaction which requires only PS I remains active even in highly aged cultures. Similar pattern of changes at different age of the culture, was also observed in Scenedesmus and Nostoc (data not shown here). Stable PS I activity in late stationary and decay phases of culture has been reported in Scenedesmus (Kulandaivelu and Senger 1976).

\subsection{Effect of anaerobic incubation on $\mathrm{H}_{2}$ evolution}

Anaerobic incubation of algal and bacterial cells has been suggested to result in reductive activation of $\mathrm{H}_{2}$ ase and $\mathrm{H}_{2}$ evolution. In order to determine whether the anaerobic incubation is a prerequisite for $\mathrm{H}_{2}$ evolution and further enhancement of the initial rate, log phase cells of Anacystis were incubated under anaerobic condition by continuously flushing with argon in dark or light for $20 \mathrm{~h}$ at $30^{\circ} \mathrm{C}$. Changes in the photosynthetic $\mathrm{O}_{2}$ and $\mathrm{H}_{2}$ evolution as a function of time of anaerobic incubation are presented in figure 3. In the presence of $\mathrm{BQ}$ or dithionite, $\mathrm{H}_{2}$ evolution could be observed even before anaerobic incubation.

Cells incubated in dark showed greater loss of $\mathrm{BQ}$ mediated reactions than those incubated in light, whereas the dithionite-mediated reaction showed no difference under both light and dark conditions. When the cells were kept under dark, the activity of water-oxidizing enzyme decreases (Gaffron 1940a, b) and the photo-

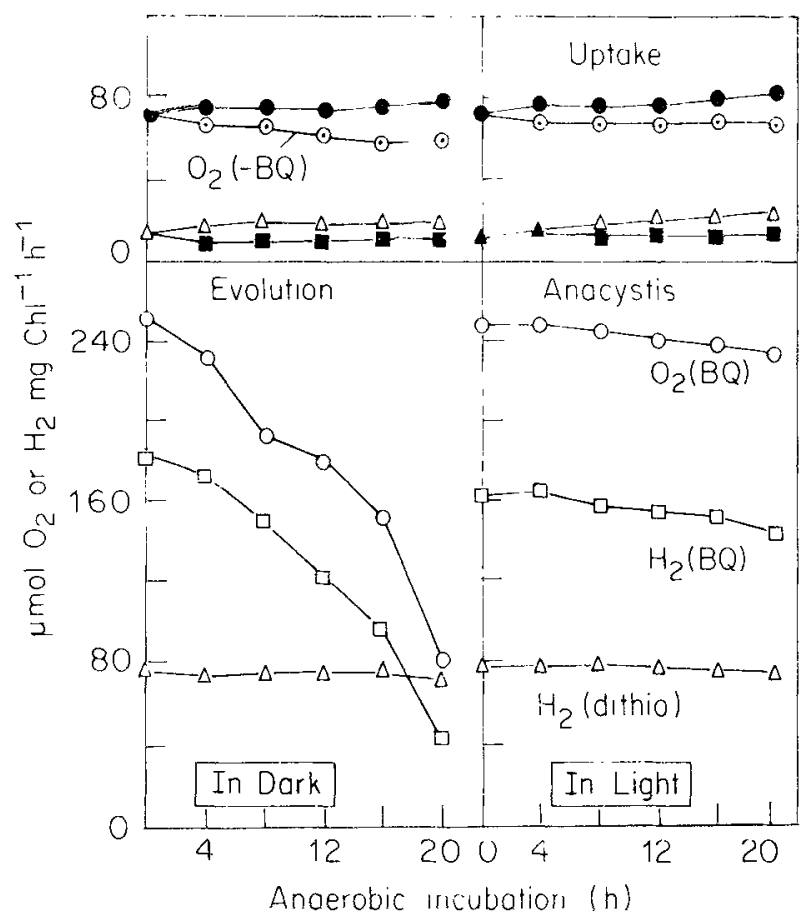

Figure 3. Effect of dark and light $\left(75 \mathrm{~W} . \mathrm{m}^{2}\right)$ anaerobic incubation on the rate $\mathrm{H}_{2}$ and $\mathrm{O}_{2}$ evolution (open symbols) and uptake (closed and partially closed symbols) in Anacystis ceils. 
synthetic electron flow becomes inhibited (Shiau and Franck 1947; Kessler 1960). However, under light the decrease is only marginal. This indicates greater stability of cells incubated in light than in dark.

\subsection{Effect of different light intensities of $\mathrm{H}_{2}$ evolution}

The rate of photosynthetic electron transport depends upon the intensity of incident light, besides several other factors. Since the $B Q$ and dithionite-mediated $\mathrm{H}_{2}$ evolution depends upon the electrons from the photosynthetic electron transport, the rate of $\mathrm{H}_{2}$ evolution is greatly influenced by the light intensity. In autotrophically grown log phase cells of Anacystis and Scenedesmus and isolated mesophyll cells of Dolichos the BQ-mediated $\mathrm{O}_{2}$ as well as $\mathrm{H}_{2}$ evolution was measured under different light intensities. In Anacystis the maximum rate of $B Q$ mediated $\mathrm{O}_{2}$ and $\mathrm{H}_{2}$ evolution was observed at $150 \mathrm{~W} . \mathrm{m}^{-2}$, whereas in Scenedesmus and in isolated mesophyll cells of Dolichos the maximum rate was found only at $450 \mathrm{~W} \cdot \mathrm{m}^{-2}$ (figure 4). In all the cases, no reduction in the rate of $\mathrm{H}_{2}$ evolution was observed even at very high light intensities. $\mathrm{H}_{2}$ evolution has been usually measured at intensities ranging from 100 to 300 W.m ${ }^{-2}$ (Schick 1971; Hillmer and Gest 1977a, b; Zurrer and Bachofen

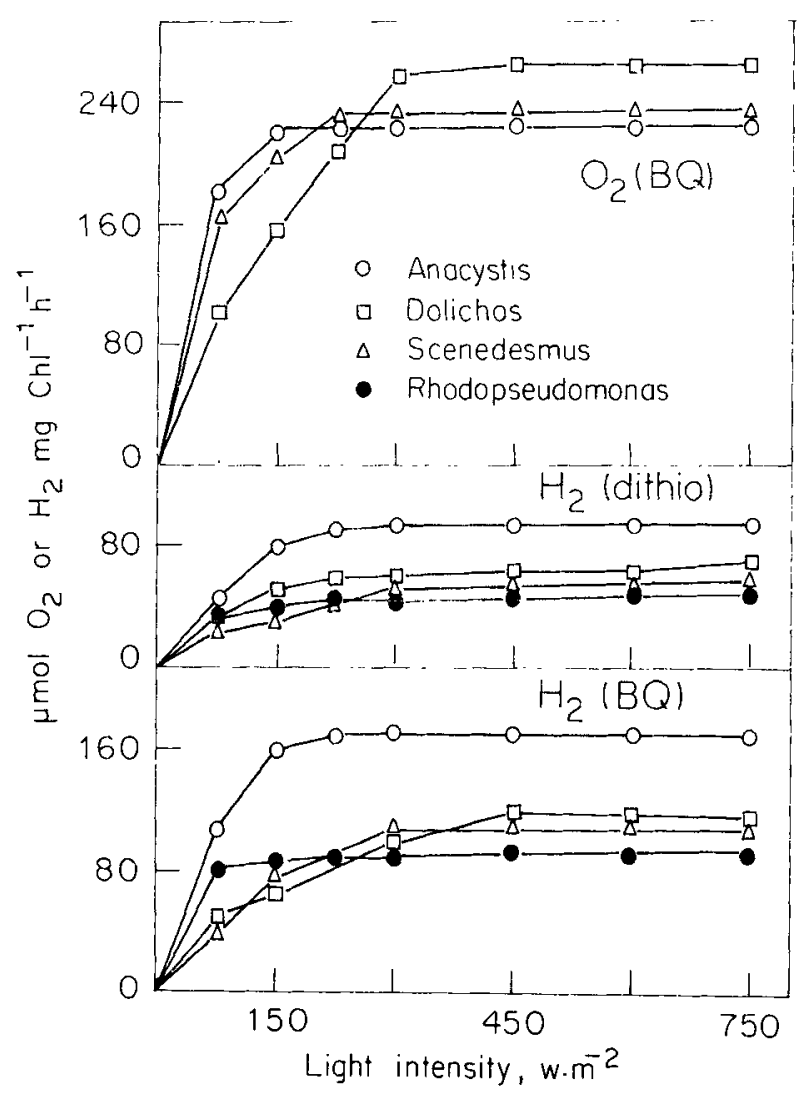

Figure 4. Effect of light intensity on the rate of $\mathrm{H}_{2}$ and $\mathrm{O}_{2}$ evolution in different cell systems. Intensity of white light was varied using calibrated neutral density filters. 


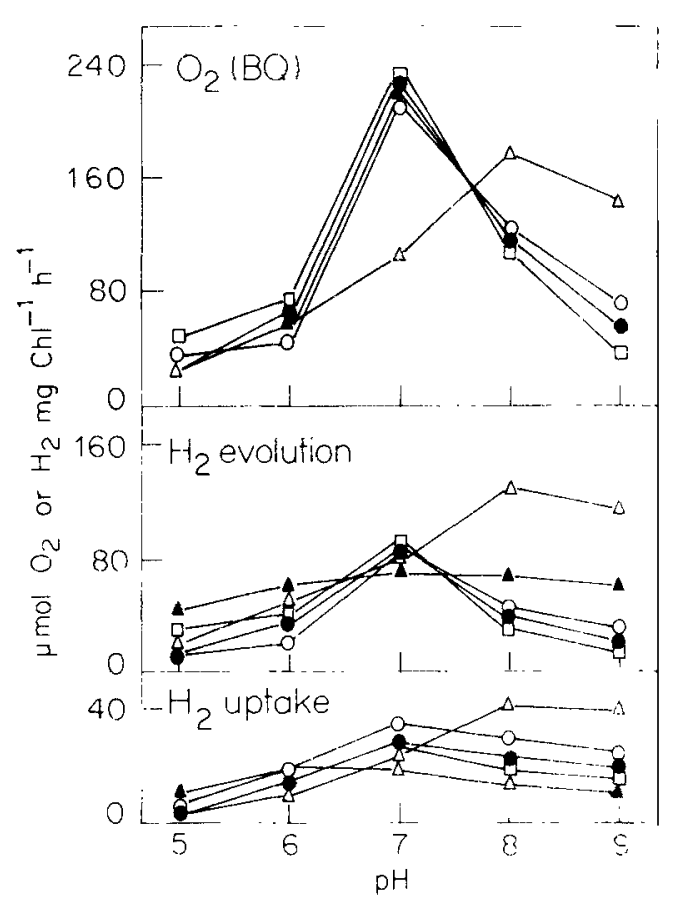

Figure 5. Effect of $\mathrm{pH}$ on the rate of $\mathrm{H}_{2}$ and $\mathrm{O}$, ewhutwon and uptake with $\mathrm{BQ}$ in different cell and chloroplast sustems. Measurement comditlom as in tert

1979). Under our measuring conditions. the changes in the rate of $\mathrm{H}_{2}$ evolution at different light intensities followed the arme pattem as that of $O_{2}$ evolution.

\subsection{Effect of $\mathrm{pH}$ on $\mathrm{H}_{2}$ elolution}

$\mathrm{H}_{2}$ ase-mediated $\mathrm{H}_{2}$ evolution and uptake reactions are highly sensitive to the $\mathrm{pH}$ of the media. Since protons are the substrates in the $\mathrm{H}_{2}$ evolution and products in the uptake reactions the proton concentration in the media may influence the extent of these reactions. To assess the effect of $\mathrm{pH}$, cells were incubated for $15 \mathrm{~min}$ in different pH media before assay. In all the cell types. the $\mathrm{BQ}-$ mediated $\mathrm{O}_{2}$ and $\mathrm{H}_{2}$ evolution showed maximum rate at neutral or weak alkaline pH range (figure 5). The low rate of aerobic $\mathrm{H}_{2}$ evolution obierved at both acidic and alkaline $\mathrm{pH}$ might be due to the fact that both extreme $\mathrm{pH}$ ranges inhibit the water oxidation and subsequent electron flow (Yocum 't al $19 x+$ ). High $\mathrm{pH}$ requirement for $\mathrm{H}_{2}$ alse activity has been reported in Anacistis (Peschek 1979b, c). Anaha'na and Nostoc (Tel-Or at al 1978).

All the above experiments clearly indicate that the rate of $\mathrm{H}_{2}$ evolution mediated by $\mathrm{BQ}$ and dithionite responds in a way similar to the photosynthetic electron transport raactions with respect to various measuring conditions.

\section{Acknowledgements}

We thank the Department of Non-Conventional Energy Sources for financial support. 


\section{References}

Allen M M 1968 J. Phycol. 41

Arnon D I 1949 Plant Physiol. 241

Bishop N I and Senger H $1971 \mathrm{In}$ : Methods Enzymol. 2353

Bose S K 1963 In: Bacterial photosynthesis (eds) H Gest, A San Pietro and L P Vernon (Yellow Springs: Antioch Press) p. 501

Calvin M 1976 Photochem. Photobiol. 23425

Clayton R K 1963 Biochim. Biophys. Acta 75312

Gaffron H 1940a Am. J. Bot. 27273

Gaffron H 1940 b Science 91529

Gnanam A and Kulandaivelu G 1969 Plant Physiol. 44 i451

Hall D O 1978 Fuel 57322

Hillmer P and Gest H 1977a J. Bacteriol. 129724

Hillmer P and Gest H 1977b J. Bacteriol. 129732

Houchins J P and Burris R H 1981a J. Bacteriol. 146215

Houchins J P and Burris R H 1981b Plant Physiol. 6871

Kessler E 1960 In Handhuch der pflanzenphysiol. Vol. V (ed.) W Ruhland (Berlin: Springer) p. 951

Kulandaivelu G and Senger H 1976 Physiol. Plant. 36157

Mitsui A 1979 In Solar hydrogen eneryy systems (ed.) T Ohta (Oxford and New York: Pergamon Press) p. 171

Peschek G A 1979a Biochim. Biophys. Acta 548187

Peschek G A 1979b Biochim. Biophys. Acta 548203

Peschek G A 1979c Arch. Microbiol. 12381

Schick H J 1971 Arch. Microbiol. 75102

Senger H 1970 Planta 90243

Senger H and Bishop N I 1979 Arch. Biochem. 14553

Shiau Y G and Franck J 1947 Arch. Biochem. 14253

Sorokin C and Krauss R W 1958 Plant Physiol. 33109

Takaoki T, Torres-Pereira J and Packer L 1974 Biochem. Biophys. Acta. 352260

Tel-Or E, Lujic L. W and Packer L 1978 Arch. Biochem. Biophys. 185185

Wang R, Healey F P and Myers J 1971 Plant Physiol. 48108

Yocum C F. Sandusky P O, Ghanotakis G and Babcock G T 1984 Advances in photosynthetic research (ed.) C Sybesma, (Den Haag: Martinus Nijhoff/Dr. Junk, W.N.V. Publishers) Vol. 2, p. 341

Zurrer H and Bachofen R 1979 Appl. Env. Microbiol. 37789 